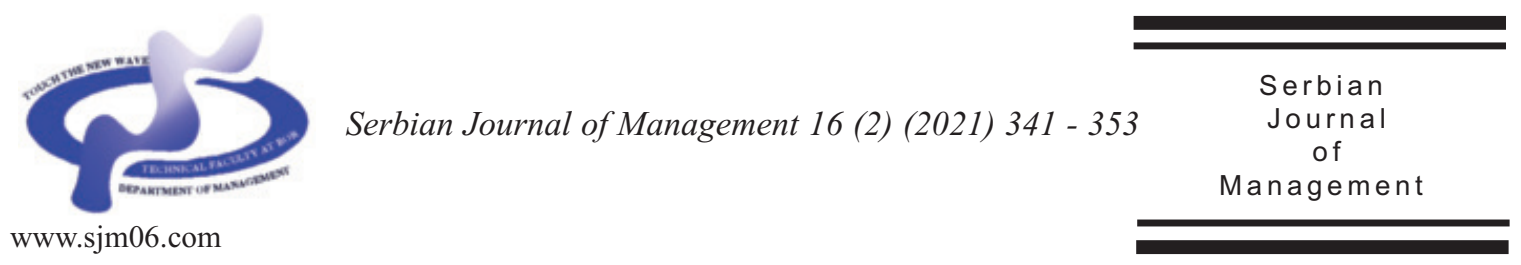

\title{
PROJECT MANAGEMENT IN MANUFACTURING ENTERPRISES
}

\author{
Jaroslav Vrchota* and Petr ̌̌ehoř \\ University of South Bohemia in Česke Budějovice, \\ Studentska 13, Česke Budějovice, Czech Republic
}

(Received 19 August 2020; accepted 25 February 2021)

\begin{abstract}
Current time of turbulent changes is related to the necessity of innovation, of both the products and the entire organization management system. However, innovation activities must be implemented in a short time. Unfortunately, most of the organizations struggle with insufficient costs and the lack of creative and active human resources. All of this might lead to a loss of market position and a decrease in competitiveness. If an organization wants to succeed on the market and survive in the long term, the trial and error method is ruled out. The project management is a possible way of dealing with the issue. Project management is characterized by a detailed examination of all the aspects of the project, their detailed planning, culminating in the implementation of the change and innovation. Therefore, the current managers need to define the precise goals, the responsible persons, and deadlines, allocate the tasks, costs and define the procedures crucial for project management clearly. Only in this way an organization is able to react to major changes quickly and without any mistakes. The aim of the paper is to evaluate the factors, important for the manufacturing enterprises in the projects, and to find out the relations of such factors. The research was carried out in 2019 in 116 manufacturing enterprises in the Czech Republic. The project managers often focus their attention on customer satisfaction and cost magnitude in evaluating of the projects.
\end{abstract}

Keywords: project, management, manufacturing enterprises, Industry 4.0

\section{INTRODUCTION}

Project management has developed into a subject discipline alongside other management functions such as operations, information technology, or finance (Kenny, 2003) and the research literature in this discipline is growing (Besner \& Hobbs, 2006; Thomas \& Mullaly, 2007). Project management is a set of concepts, tools, and techniques on how to execute projects on time, within budget, and to required customer specifications within the context of an explicit company strategy (Morris, 2013).

\footnotetext{
* Corresponding author: vrchota@ef.jcu.cz
}

DOI: $10.5937 /$ sjm16-28044 
Project management is about implementing a change program (Norrie \& Walker, 2004; Stoycheva \& Antonova, 2018). Project management shall therefore be defined as applying skills and methods to planning organizing, directing, and controlling of company resources to meet the projects objectives (Lückmann \& Feldmann, 2017). The recognition of the strategic importance of managing projects in the corporate world is rapidly increasing (Gomes \& Romão, 2016). Project-based organizations are becoming increasingly widespread and important for the modern economy and society (Lundin et al., 2015). Project managers are perceived to be leading a diverse set of people with little direct control over the team members (Cleland \& Ireland, 2006). Management of project-based organizations is an important research topic due to the wide dissemination of this organizational form and its idiosyncratic challenges. A number of studies emphasized the differences between project-based and more traditional forms of organizations (Sydow et al., 2004; Söderlund \& Tell, 2011). Project-based firms are organized around projects (Gann \& Salter, 2000). Issues that have been addressed are the characteristics of project-based organizations (Greenwood et al., 2005; Whitley, 2006), the transformation of functional organizations to project-based organizations (Lindkvist, 2004) and knowledge exchange within these organizations (Robertson et al., 2003; Salter \& Gann, 2003).

Projects represent important challenges for organizations and ensuring that projects are aligned with strategy is one of the key factors for success of organizations (Petro \& Gardiner, 2015). One of the most basic functions of projects is to serve as a component to business operations (Brlečić
Valčić et al., 2016). Projects can also be effective in implementing corporate strategy (Sánchez \& Schneider, 2014; Hyväri, 2016). Even though project tools and techniques have been identified as key to the success of SMEs by several authors (Cooke-Davies, 2002; Turner et al., 2010). The literature suggests that multiple benefits can be achieved from having a mature project management system in place (Kwak \& Ibbs, 2000; Bryde, 2003). Belout and Gauvreau (2004) discuss the relevance of human aspects in project success. White and Fortune (2002) state the importance of senior management support in a large range of sectors. Organizational support_-viable with top management support - was positively associated with project success (Fedor et al., 2003). Many factors, which drive project performance, are derived from the human side (Thamhain, 2004; Slavić et al., 2014). A worldwide benchmark study of organizational project management practices involving more than 550 organizations. Mullaly (2004) identified several key attributes and drivers of project management success and failure. They are establishing an environment of trust, creating transparency of decision making, creating consistent processes, ensuring understanding of expectations, and delivering results. Drivers of project management failure include failing to define processes and roles, failure to develop and use a project selection process, not mandating consistent processes, and failure to manage the attainment of organizational outcomes. Despite all of the positive benefits that a project management brings to organizations, its adoption may be negatively impacted by some factors that can prevent its consistent, successful implementation and maintenance (McHugh \& Hogan, 2011). 
The failure can be caused by misunderstood requirements, optimistic schedules and budgets (Bitoleuova et al., 2020), poor risk assessment (Savić et al., 2014), inconsistent standards (Ruso et al., 2017) and lack of training (Lambovska, 2018), failure to manage resources properly, unclear project charter and overall lack of communications. The lacking awareness of organizational issues, poor alignment of IT adoption to the business strategy, changed customer requirements and the project size and complexity all can contribute to project failure (Chua, 2009; Milošević et al., 2019). Projects continue to fail at an astounding rate regardless of the type of project, or the industry from which they originate (Ramazani \& Jergeas, 2015). 75\% of projects failed before they ever reached implementation (Harrington \& Frank, 2015). Multiple authors attributed project failure to problems related to lack of or failed communication within projects (Longenecker \& Longenecker, 2014; Dwivedi et al., 2015). Kerzner (2013) observed that projects fail to meet time and cost targets due to poor morale, lack of motivation, poor human relations, poor productivity, and lack of commitment from employees. Multiple authors (Albliwi et al., 2014; Longenecker \& Longenecker, 2014) also concluded that insufficient project sponsorship indicated a lack of clear senior leader ownership and support of projects.

\section{EXPERIMENTAL (RESEARCH)}

The aim of the paper is to evaluate the factors, important for the manufacturing enterprises in the projects, and to find out the relations of such factors. At the same time, the current trends (industry 4.0, quality of employees) affecting these organizations are assessed. The research was carried out in 2019 in 116 manufacturing enterprises in the Czech Republic. The manufacturing enterprises are used in the analysis due to their higher technological demands and closer relationship to Industry 4.0, which is also a part of the research. The sample of enterprises was selected on the basis of their size to best correspond to the real distribution of the enterprises in the Czech Republic.

The data were collected in the form of electronic questioning. The managing directors of the enterprises were addressed. Out of a total of 116 enterprises, 74 use project management elements and they implement the projects. Such enterprises were asked what factors (areas) they evaluate to analyze the success of the project. The questions were open and therefore the enterprises were not forced to choose from pre-prepared answers. After that, the answers were classified into six groups (customer satisfaction, terms, costs, efficiency, quality, others) by a team of five experts (the project managers and the authors of the paper). As each enterprise might fit into more groups, correlation tests were performed between the groups, using Pearson correlation coefficient, supposing normality of data. In the correlation, an $\mathrm{H} 0$ null hypothesis is formulated, saying that the groups do not correspond each other compared to an alternative hypothesis, saying that the first factor influences the second one.

$$
\mathrm{H} 0: \rho(\mathrm{X}, \mathrm{Y})=0 ; \mathrm{HA}: \rho(\mathrm{X}, \mathrm{Y}) \neq 0
$$

In order to use Pearson correlation coefficient, it is necessary to prove the normality of both variables (Freund et al., 2010). To analyse the one-dimensional 
normality of

$R=\frac{r}{\sqrt{1-r^{2}}} \cdot \sqrt{n-2}$

Histograms with Shapiro-Wilk test were used (p-value), followed by Q-Q plots. After that, the data were analysed (Williams et al., 2017) using Pearson coefficient:

$$
r=\frac{\sum\left(x_{i}-\bar{x}\right) \cdot\left(y_{i}-\bar{y}\right)}{\sqrt{\sum\left(x_{i}-\bar{x}\right)^{2} \cdot \sum\left(y_{i}-\bar{y}\right)^{2}}}=\frac{S_{x y}}{S_{x} \cdot S_{y}}
$$

For the sake of clarity, the results are summarized in a table and statistically compared to their interdependencies in the Statistica software, version 12. Subsequently, the hypotheses dealing with the differences of the enterprises were categorized by the groups, using MannWhitney test in order to determine in which groups are the enterprises different in an emphasis on a certain factor, with a statistical significance of 0.05 . In the analysis, a null hypothesis that the enterprises that follow and not follow a certain factor match on the basis of the data analyzed, and an alternative hypothesis that the enterprises that follow a certain factor reach a higher level in that factor. The data were tested using the Wilcoxon two-sample test (Freund et al., 2010) and its asymptotic variants. It is a nonparametric two-sample test, which is most often used when the presumption of data normality is not followed. A slight violation of normality for the samples greater than 30 does not have a major impact on the test results (Devore, 2015).

\section{RESULTS AND DISCUSSION}

In the sample, mechanical engineering enterprises are the most common (43\%), followed by production of non-metal products $(14 \%)$; household production $(13 \%)$ and other (31\%). In terms of the size of the enterprise, there are enterprises from five employees up to 680 employees with an average number of 199 employees. The sample includes 64 non-foreign owned and local enterprises, compared to 52 foreign owned enterprises. At the same time, $38 \%$ of the sample regularly cooperates with universities and research institutes. There are 68 enterprises with a written strategy. Industry 4.0 is mentioned in $72 \%$ of the strategies. Such figure is rather high, so it is expected that the enterprises focus on future development and innovation is a matter of course for them. The enterprises were asked to report the factors they focused on in terms of assessing the success of a project. The results are summarized in the Figure 1, showing that most of the enterprises focus on a customer, and a client, together with the project costs. Consequently, the enterprises consider the monitoring of project deadlines and time horizons together with the overall effectiveness of the project to be significant. Around 17 enterprises focus on quality indicators. The group of other indicators included enterprises that defined factors such as: safety, sustainability, risks, design, but also know-how acquired, which were mentioned by six enterprises.

After that, the factors were analysed, using Pearson correlation coefficient, so that it was possible to assess the common factors - see the Table 1. The correlation was monitored at a significance level of 0.05 and it was confirmed among factors focused on efficiency and customer satisfaction, when 
the $p$-value was close to zero and the coefficient value was 0.328 . Furthermore, for the factors focusing on terms and costs, there is correlation strength of 0.487 at $p$-value close to zero, so that it is the strongest correlation. A positive correlation was also found between quality and cost, where the $p$ value equals 0.016 and the correlation value is 0.224 .

The results as reported in the Table 1 are considered surprising, as the general assumption is that the enterprises follow all three main project areas (scope, resources, time) equally. However, this assumption is not proved. For this reason, the enterprises were further tested using the MNW test so that the differences between different groups of the enterprises in terms of monitored project success factors are possible to be demonstrated. Testing focused on two current directions in the management of the enterprises, one of which is the quality of employees (number, education, knowledge), assuming that the enterprises with quality employees will monitor various factors of project success, and the second is related to 4.0 (introduction of new technologies, priority of introduction, perception of the company in terms of Industry 4.0 and the number of implemented projects).

The Table 2 reports the indicators of these directions in relation to the groups of project success factors, where the p-value is always shown. The hypotheses are tested at a significance level of 0.05 . Null hypothesis is always as $\mathrm{H} 0=x 0.50-y 0.50$, compared to the alternative of $\mathrm{HA}=x 0.50>y 0.50$; and $\mathrm{X}$ $=$ are the enterprises that put emphasis on the group and $\mathrm{Y}=$ those that do not put emphasis on this group of success factors. The Table 2 also reports the value of $Z$, so after rejecting null hypothesis it reports the group of the enterprises with greater values. In relation to customer satisfaction, the majority of

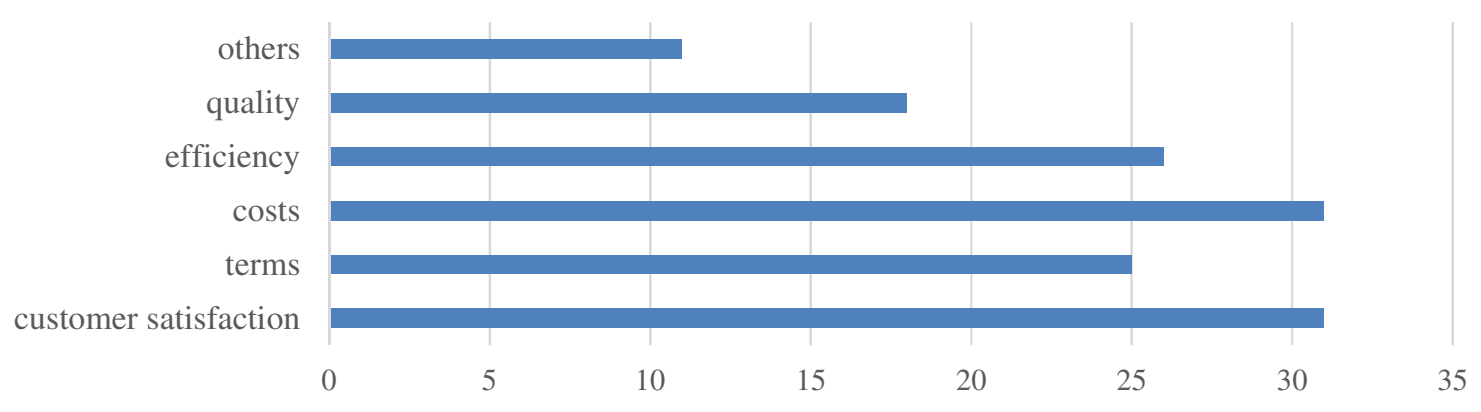

Figure. 1. Share of different indicators in the enterprises

Table 1. Correlation coefficient of the factors

\begin{tabular}{lllllll}
\hline & $\begin{array}{l}\text { Customer } \\
\text { satisfaction }\end{array}$ & Terms & Costs & Efficiency & Quality & Others \\
\hline Customer satisfaction & 1.000 & 0.060 & 0.073 & 0.328 & 0.062 & 0.002 \\
Terms & 0.060 & 1.000 & 0.487 & 0.068 & 0.179 & 0.044 \\
Costs & 0.073 & 0.487 & 1.000 & 0.000 & 0.224 & 0.069 \\
Efficiency & 0.328 & 0.068 & 0.000 & 1.000 & 0.053 & -0.034 \\
Quality & 0.062 & 0.179 & 0.224 & 0.053 & 1.000 & -0.059 \\
Others & 0.002 & 0.044 & 0.069 & -0.034 & -0.059 & 1.000 \\
\hline
\end{tabular}


indicators failed to reject null hypothesis, so that the enterprises that emphasize this factor do not differ in the number and the structure of employees, nor they do report to be the Industry 4.0 enterprises. On the other hand, it was possible to prove different attitude of such enterprises in relation to Industry 4.0 implementation planning $(p$-value $=0.039)$ and the number of implemented projects $(p-$ value $=0.025$ ). It suggests that the enterprises focusing on customer satisfaction tracking are more technology-oriented in the enterprise and, at the same time they are implementing more projects over the year, as deduced from the positive value of the $Z$ statistics tested. The distribution of data in relation to planning of Industry 4.0, and customer satisfaction is reported by the left box-plot in Figure 2.

In relation to the enterprises focusing on deadlines, the indicators failed to reject null hypothesis, at the level of significance $(\alpha=0.05)$. The indicator focused on the subjective perception of the position of the enterprise in relation to Industry 4.0 was the closest, as the resulting $p$-value is at the level of 0.061. Another tested group, consisting of the enterprises that emphasize the costs of projects, proved the difference in terms of the number of university educated employees. Due to its $p$-value (0.031) and positive $Z$ value, it is revealed that the

Table 2. Test statistics

\begin{tabular}{|c|c|c|c|c|c|c|c|c|c|c|c|c|}
\hline & \multicolumn{2}{|c|}{$\begin{array}{l}\text { Customer } \\
\text { satisfaction }\end{array}$} & \multicolumn{2}{|c|}{ Terms } & \multicolumn{2}{|c|}{ Costs } & \multicolumn{2}{|c|}{ Efficiency } & \multicolumn{2}{|c|}{ Quality } & \multicolumn{2}{|c|}{ Others } \\
\hline & Z & p-value & $\mathrm{Z}$ & p-value & $\mathrm{Z}$ & p-value & $\mathrm{Z}$ & p-value & $\mathrm{Z}$ & $\mathrm{p}$-value & $\mathrm{Z}$ & p-value \\
\hline Number of employees & 1.094 & 0.274 & 0.583 & 0.560 & 1.551 & 0.121 & 1.238 & 0.216 & 2.048 & 0.041 & 1.056 & 0.291 \\
\hline Ratio of IT specialists & 0.953 & 0.340 & 0.725 & 0.468 & 1.418 & 0.156 & 0.532 & 0.595 & 1.830 & 0.067 & 3.667 & 0.000 \\
\hline $\begin{array}{l}\text { Ratio of university educated } \\
\text { workers }\end{array}$ & 1.252 & 0.211 & 0.229 & 0.819 & 2.155 & 0.031 & 2.537 & 0.011 & 2.041 & 0.041 & 2.045 & 0.041 \\
\hline $\begin{array}{l}\text { How much do you plan to } \\
\text { seduce Industry } 4.0 ?\end{array}$ & 2.064 & 0.039 & -0.383 & 0.702 & 1.847 & 0.065 & 0.140 & 0.888 & 0.985 & 0.324 & -0.361 & 0.718 \\
\hline $\begin{array}{l}\text { How much do you rank } \\
\text { among the companies with } \\
\text { Industry } 4.0 ?\end{array}$ & 1.639 & 0.101 & 1.874 & 0.061 & 0.886 & 0.376 & 0.234 & 0.815 & 0.797 & 0.426 & 0.675 & 0.500 \\
\hline $\begin{array}{l}\text { What is the priority of } \\
\text { Industry } 4.0 \text { in your } \\
\text { organization? }\end{array}$ & 1.447 & 0.148 & 0.714 & 0.475 & 0.955 & 0.340 & 0.191 & 0.849 & 0.385 & 0.700 & 1.407 & 0.159 \\
\hline $\begin{array}{l}\text { How many projects did you } \\
\text { realize last year? }\end{array}$ & 2.249 & 0.025 & 0.262 & 0.793 & 1.462 & 0.144 & 1.797 & 0.042 & 2.299 & 0.022 & 0.524 & 0.601 \\
\hline
\end{tabular}
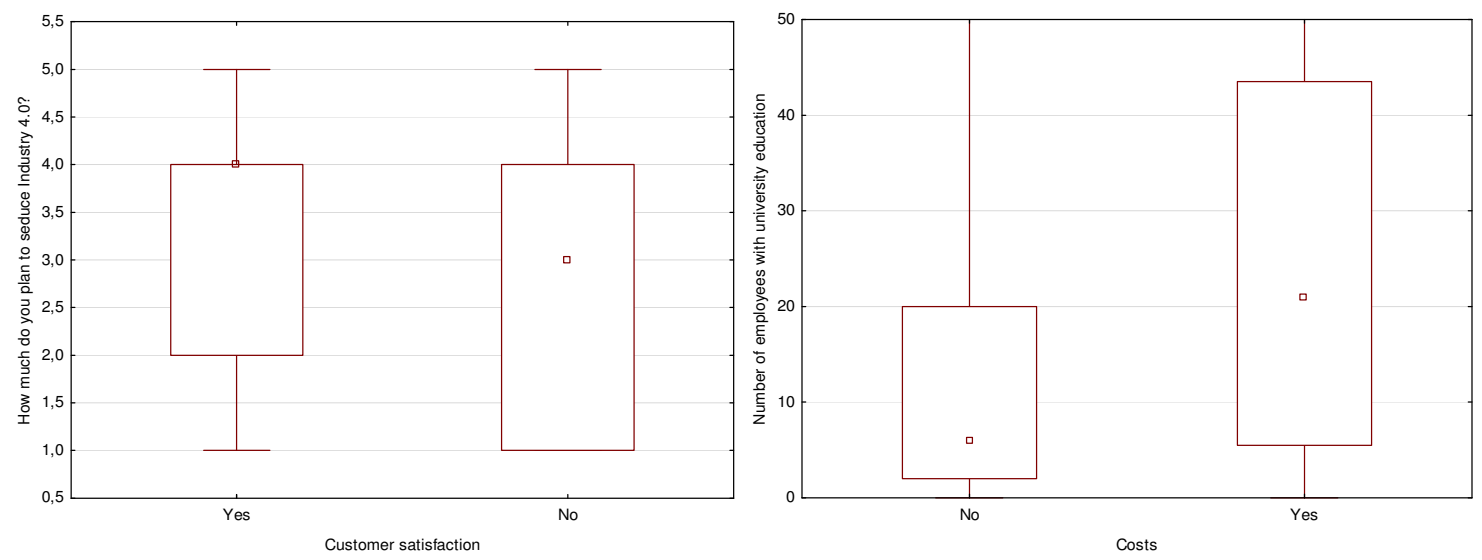

Figure. 2. (a) Customer satisfaction, (b) Costs 
enterprises employing more undergraduates emphasize the cost of project management. Such conclusion is also supported by the right plot in Figure 2.

Regarding the enterprises, monitoring their efficiency, null hypothesis of agreement between both groups was rejected in the enterprises with higher numbers of university graduates ( $p$-value $=0.011)$ and higher number of implemented projects ( $p$ value $=0.042$ ). The left plot in Figure 3 shows the median displacement and wider distribution of half the data for efficiency monitoring. The upper quartile of the values starts at 30 projects, while for the nonefficiency enterprises this quartile starts at 12 projects. For the other factors, null hypothesis could not be rejected and we can therefore continue to assume that such enterprises do not differ in the indicators for the efficiency. In relation to quality-oriented factors, null hypothesis of the agreement between the two groups was rejected in three cases. The significant differences were found in terms of the number of employees, suggesting that qualitative indicators are significant for the large enterprises ( $p$ value $=0.041$ ) and also for the enterprises with a higher proportion of university graduates $(p$-value $=0.041)$. In the third case, there are the enterprises implementing a larger number of projects $(p$-value $=0.022)$ in one year. They also place more emphasis on quality, compared to the enterprises with a lower number of projects. The right figure in Figure 3 shows box-plots for the enterprises with an emphasis on quality in their projects and the number of projects implemented. It is apparent that the enterprises with a focus on quality implement more projects. Regarding the other factors, null hypothesis could not be rejected. The last area of the research was the category of other indicators, carried out in twelve enterprises. The group of other indicators included indicators that defined the factors such as: safety, sustainability, risks, design, and know-how acquired, mentioned by six enterprises. Regarding this group, it is proved that the enterprises report a higher proportion of IT specialists ( $p$ value $=0,000$ ) together with a higher proportion of university educated employees. It can therefore be concluded that enterprises equipped with quality knowledge capital are more often focused on areas other than time, resources and scope in their projects.

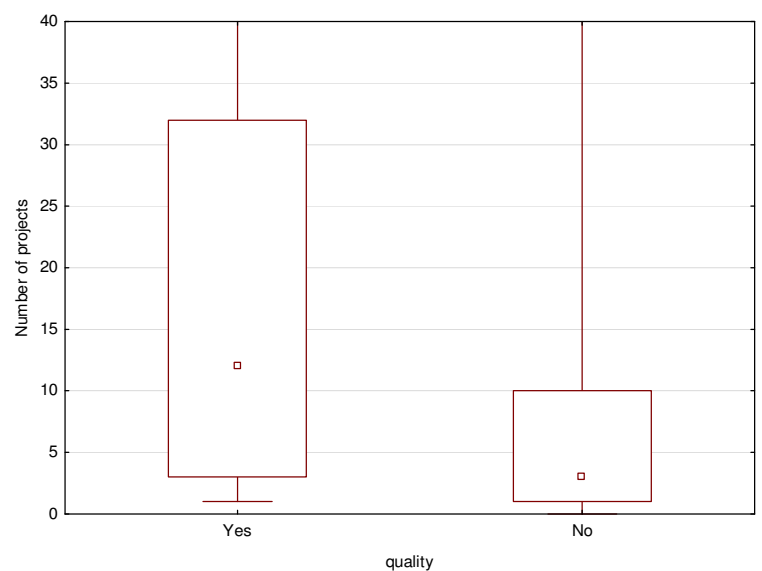

Figure. 3. (a) Efficiency, (b) Quality 


\section{CONCLUSION}

Current time is rather full of dynamic changes, so that it is sometimes defined as turbulent; the classic approach to business process management based on deviationbased regulation is no longer sufficient (Rolínek \& Řehoŕ, 2008). One of the solutions is the use of modern project management tools. Project management plays a significant role in many countries of the world as an effective and efficient tool in planning and organizing processes, crisis management and time management. It is clear that project management is driving small and medium organisations. There is therefore a need to create a more sustainable way of utilising project management tools (Vrchota \& Řehoř, 2019a). Project management tools and techniques enable the managers to respond flexibly to changes, new information and manage under uncertain conditions to meet the basic goals of each project - to meet the requirements of limited time and budget (Novotná \& Volek, 2018; Veselovská et al., 2018). Almost $2 / 3$ of the organizations in the Czech Republic are managed through projects (Pech \& Vaněček, 2018). In evaluating the success of their projects, the managers most often focus on customer satisfaction (Cooper et al., 2002; Boehm \& Turner, 2005) and project costs (Agarwal \& Rathod, 2006; Ibusuki \& Kaminski, 2007). which is in line with the research. However, they are the least interested in quality. It is a significant shift compared to less recent studies (Griffin \& Page, 1996; Black et al., 2000) where quality was favoured. The strongest correlation between the six monitored evaluation factors was found between the project deadlines and costs. In general, it is considered important in project management to monitor all three major project areas (scope, resources, time) equally, as reported by PMBOK ${ }^{\circledR}$ (2017).

Furthermore, the authors tested two current trends of the management of the manufacturing enterprises - quality of employees and Industry 4.0, using six factors of evaluation of project success. It was proved that the enterprises focused on monitoring customer satisfaction are more oriented on Industry 4.0 and at the same time they implement more projects. Also, the relation to the quality of employees (Anantatmula \& $\operatorname{Rad}, 2018$ ) is proved, i.e. the enterprises with more universityeducated employees, emphasize cost in terms of the project management, together with the efficiency and quality - the relations between quality staff and project efficiency was also proved by Fatema and Sakib (2017), who also emphasized teamwork. Project management is considered by Western countries to be a common knowledge that every manager, and a worker, who is involved in any way in project work, has to apply. It is a proven method of quality management of costs, deadlines and virtually the entire competitive ability of the enterprise. Mastering the knowledge of project management and its use in practice should definitely be in the centre of attention of the SME managers (Vrchota \& Řehoř, 2019b; Řehoř \& Vrchota, 2018). In the current field of scientific research, there is much space for exploring the human factors influencing the success of a project; however a few methods and approaches only that would help quantify human behaviour in the project. Project management thus awaits development in which a greater consideration is given to communication and other soft factors of project management and the efforts should be made to find a new quantitative approach to such issue. 


\section{Acknowledgment}

This article has been presented with the financial support of the project GAJU 047/2019/S.

\section{References}

Agarwal, N., \& Rathod, U. (2006). Defining „success" for software projects: An exploratory revelation. International Journal of Project Management, 24 (4), 358-370.

Albliwi, S., Antony, J., Abdul Halim Lim, S., \& Van der Wiele, T. (2014). Critical failure factors of Lean Six Sigma: A systematic literature review. The International Journal of Quality \& Reliability Management, 31 (9), 1012-1030.

Anantatmula, V.S., \& Rad, P.F. (2018). Role of Organizational Project Management Maturity Factors on Project Success. Engineering Management Journal, 30 (3), 165-178.

Belout, A., \& Gauvreau, C. 2004). Factors influencing project success: the impact of human resource management. International Journal of Project Management, 22 (1), 1-11.

Besner, C., \& Hobbs, B. (2006). The perceived value and potential contribution of project management practices to project success. Project Management Journal, 37 (3), 37-48.

Bitoleuova, Y., Aibossynova, D., Kabdullina, G., Baimukhasheva, M., \& Tazhibaeva, R. (2020). Modern trends in management of the budget system. Serbian Journal of Management, 15(1), 55-68.

Black, C., Akintoye, A., \& Fitzgerald, E. (2000). Analysis of success factors and benefits of partnering in construction. International Journal of Project Management, 18 (6), 423-434.
Boehm, B., \& Turner, R. (2005). Management challenges to implementing agile processes in traditional development organizations. IEEE Software, 22 (5), 3039.

Brlečić Valčić, S., Dimitrić, M., \& Dalsaso, M. (2016). Effective Project Management Toolsf or Modern Organizational Structures. Annals of Maritime Studies / Pomorski Zbornik, 51 (1), 131-145.

Bryde, D.J. (2003). Modelling project management performance. International Journal of Quality and Reliability Management, 20 (2), 229-254.

Cleland, D.I., \& Ireland, L.R. (2006). Project management: Strategic design and implementation. McGraw-Hill, New York.

Cooke-Davies, T. (2002). The real success factors on projects. International Journal of Project Management, 20 (3), 185190.

Cooper, R.G., Edgett, S.J., \& Kleinschmidt, E.J. (2002). Optimizing the stage-gate process: What best-practice companies Do-II. Research Technology Management, 45 (6), 43-49.

Devore, J.L. (2015). Probability and Statistics for Engineering and the Sciences. Brooks Cole. Boston, MA

Dwivedi, Y.K., Wastell, D., Laumer, S., Henriksen, H.Z., Myers, M.D., Bunker, D., \& Srivastava, S.C. (2015). Research on information systems failures and successes: Status update and future directions. Information Systems Frontiers, 17 (1), 143157.

Fatema, I., \& Sakib, K. (2017). Factors Influencing Productivity of Agile Software Development Teamwork: A Qualitative System Dynamics Approach. 2017 24th Asia-Pacific Software Engineering Conference (APSEC), 737-742. 


\section{УПРАВЉАЊЕ ПРОЈЕКТИМА У ПРОИЗВОДНИМ ПРЕДУЗЕЋИМА}

\section{Jaroslav Vrchota, Petr Řehoř}

\section{Извод}

Тренутно време турбулентних промена везано је за неопходност иновација, како производа, тако и целокупног система управљања организацијом. Међутим, иновационе активности морају бити спроведене у кратком року. Нажалост, већина организација се бори са недовољним финансијским средствима и недостатком креативних и активних људских ресурса. Све ово може довести до губитка тржишне позиције и смањења конкурентности. Ако организација жели да успе на тржишту и опстане дугорочно, метод покушаја и грешке је искључен. Пројектно управљање је могући начин решавања проблема. Пројектно управљање карактерише детаљно испитивање свих аспеката пројеката, њихово детаљно планирање, које кулминира имплементацијом промена и иновација. Дакле, садашњи руководиоци треба да дефинишу прецизне циљеве, одговорна лица и рокове, распореде задатке, трошкове и јасно дефинишу процедуре кључне за управљање пројектима. Само на тај начин организација може брзо и без грешке да реагује на велике промене. Циљ рада је да се процене фактори од значаја за производна предузећа у пројектима и да се открију односи ових фактора. Истраживање је спроведено 2019. године у 116 производних предузећа у Чешкој. Менаџери пројекта често фокусирају своју пажњу на задовољство купаца и величину трошкова приликом евалуације пројеката.

Кључне речи: пројекат, менаџмент, производна предузећа, индустрија 4.0

Fedor, D.B., Ghosh, S., Caldwell, S.D., Maurer, T.J., \& Singhal. V.R. (2003). The Effects of Knowledge Management on Team Members' Ratings of Project Success and Impact. Decision Sciences, 34 (3), 513-539.

Freund, R.J., Wilson, W.J., \& Mohr, D.L. (2010). Statistical methods. Elsevier. Amsterdam.

Gann, D.M., \& Salter, A.J. (2000). Innovation in project-based, serviceenhanced firms: the construction of complex products and systems. Research Policy, 29 (7-8),955-972.

Gomes, J., \& Romão, M. (2016). Improving project success: A case study using benefits and project management. Procedia Computer Science, 100, 489-497.

Greenwood, R., Li, S.X., Prakash, R., \&
Deephouse, D.L. (2005). Reputation, Diversification, and Organizational Explanations of Performance in Professional Service Firms. Organization Science, 16 (6), 661-673.

Griffin, A., \& Page, A.L. (1996). PDMA success measurement project: Recommended measures for product development success and failure. Journal of Product Innovation Management 13 (6), 478-496.

Harrington, H.J., \& Frank, V. (2015). Cultural change management. International Journal of Innovation Science, 7 (1), 55-74.

Hyväri, I. (2016). Roles of top management and organizational project management in the effective company strategy implementation. Procedia - Social 
and Behavioral Sciences, 226, 108-115.

Chua. A. (2009). Exhuming IT projects from their graves: an analysis of eight failure cases and their risk factors. The Journal of Computer Information Systems, 49 (3), 3139.

Ibusuki, U., \& Kaminski, P.C. (2007). Product development process with focus on value engineering and target-costing: A case study in an automotive company. International Journal of Production Economics, 105 (2), 459-474.

Kenny, J. (2003). Effective projectmanagement for strategic innovation and change in an organizational context. Project Management Journal, 34 (1), 43-53.

Kerzner, H. (2013). Project Management a Systems Approach to Planning, Scheduling, and Controlling. Wiley, Hoboken, NJ.

Kwak, Y.H., \& Ibbs, C.W. (2000). Calculating project management's return on investment. Project Management Journal, 31 (2), 38-47.

Lambovska, M.R. (2018). Control on teams: A model and empirical evidence from Bulgaria. Serbian Journal of Management, 13 (2), 311-322

Lindkvist, L. (2004). Governing ProjectBased Firms: Promoting Market-Like Processes within Hierarchies. Journal of Management and Governance, 8 (1), 3-25.

Longenecker, C.O., \& Longenecker, P.D. (2014). Why hospital improvement efforts fail: A view from the front line. Journal of Healthcare Management, 59 (2), 147-159.

Lückmann, P., \& Feldmann, C. (2017). Success Factors for Business Process Improvement Projects in Small and Medium Sized Enterprises - Empirical Evidence. Procedia Computer Science, 121, 439-445.

Lundin, R.A., Arvidsson, N., Brady, T., Ekstedt, E., Midler, C., \& Sydow, J. (2015).
Managing and Working in Project Society: Institutional Challenges of Temporary Organizations. Cambridge University Press, Cambridge, UK.

McHugh, O., \& Hogan, M. (2011). Investigating the rationale for adopting an internationally-recognised project management methodology in Ireland: The view of the project manager. International Journal of Project Management, 29 (5), 637646.

Milošević, I., Mihajlović, I., \& Stojanović, A. (2019). Dominant factors of SMEs failure-Multigroup confirmatory factor analysis. Serbian Journal of Management, 14 (2), 345-360.

Morris, P.W. (2013). Reconstructing project management. Wiley. New York, NY.

Mullaly, M.E. (2004). PM success in organizations, trends, best practices and next steps. Proceedings of the 18th IPMA Global Congress 2004, Moscow.

Norrie, J., \& Walker, D.H.T. (2004). A Balanced Scorecard Approach to Project Management Leadership. Project Management Journal, 35 (4), 47-56.

Novotná, M., \& Volek, T. (2018). Efficiency of production factors in the EU. DETUROPE - The Central European Journal of Regional Development and Tourism, 10 (2), 147-168.

Pech, M., \& Vaněček, D. (2018). Methods of lean production to improve quality in manufacturing. Quality Innovation Prosperity, 22 (2), 1-15.

Petro, Y., \& Gardiner, P. (2015). An investigation of the influence of organizational design on project portfolio success, effectiveness and business efficiency for project-based organizations. International Journal of Project Management, 33 (8), 1717-1729.

Project Management Institute (Ed.). 
(2017). A guide to the project management body of knowledge. Project Management Institute. Newtown Square, PA.

Ramazani, J., \& Jergeas, G. (2015). Project managers and the journey from good to great: The benefits of investment in project management training and education. International Journal of Project Management, 33 (1), 41-52.

Robertson, M., Scarbrough, H., \& Swan, J. (2003). Knowledge Creation in Professional Service Firms: Institutional Effects. Organization Studies, 24 (6), 831857.

Rolínek, L., \& Ř Rehoř, P. (2008). Strategic management and measurement of competitiveness of regions on example of countries EU. Journal of Central European Agriculture, 9 (1), 17-22.

Ruso, J., Filipović, J., \& Ranković, B. (2017). The Serbian quality infrastructure as viewed by the quality managers. Serbian Journal of Management, 12 (2), 291-301.

Řehoř, P., \& Vrchota, J. (2018). Remuneration in small and middle-sized enterprises with project management. Procedia Computer Science, 138, 829-834.

Salter, A.J., \& Gann, D.M. (2003). Source of Ideas for Innovation in Engineering Design. Research Policy, 32 (8), 1309-1324.

Sánchez, M.A., \& Schneider, D.E. (2014). Project management, strategic management and sustainable development: A review of the literature. Revista Metropolitana De Sustentabilidade, 4 (3), 28-49.

Savić, M., Dordević, P., Nikolić, D., Mihajlović, I., \& Živković, Z. (2014). Bayesian inference for risk assesment of the position of study program within the integrated university: A case study of engineering management at technical faculty in Bor. Serbian Journal of Management, 9 (2), 231-240.

Slavić, A., Berber, N., \& Leković, B. (2014). Performance management in international human resource management: Evidence from the cee region. Serbian Journal of Management, 9 (1), 45-58.

Söderlund, J., \& Tell, F. (2011). The PForm Corporation: Contingencies, Characteristics and Challenges, in Morris, P.W.G., Pinto, J.K., and Söderlund, J. (Eds.) The Oxford Handbook of Project Management, Oxford, UK.

Stoycheva, B., \& Antonova, D. (2018). Investigating factor interactions in formalising the process of developing new products. Serbian Journal of Management, 13 (1), 173-184.

Sydow, J., Lindkvist, L., \& DeFillippi, R. (2004). Project-Based Organizations, Embeddedness and Repositories of Knowledge: Editorial. Organization Studies, 25 (9), 1475-1489.

Thamhain, H.J. (2004). Linkages of Project Environment to Performance: Lessons for Team Leadership. International Journal of Project Management, 22 (7), 533544.

Thomas, J., \& Mullaly, M. (2007). Understanding the value of project management: first steps on an international investigation in search of value. Project Management Journal, 38 (3), 74-89.

Turner, R., Ledwith, A., \& Kelly, J. (2010). Project Management in small to medium-sized enterprises: Matching processes to the nature of the firm. International Journal of Project Management, 28 (8), 744-755.

Veselovská, L., Kožárová, M., \& Závadský, J. (2018). Relationship between information sharing and flexibility in management of enterprises in automotive 
industry: An empirical study. Serbian Journal of Management, 13 (2), 381-393.

Vrchota, J., \& Řehoř, P. (2019a). Project management and innovation in the manufacturing industry in Czech Republic. Procedia Computer Science, 164, 457-462.

Vrchota, J., \& Řehoř, P. (2019b). The influence of a human resource strategy to the function of human resource processes in small and medium-sized enterprises (SMEs). Serbian Journal of Management, 14 (2), 299-314.

White, D., \& Fortune, J. (2002). Current practice in project management - an empirical study. International Journal of Project Management, 20 (1), 1-11.

Whitley, R. (2006). Project-Based Firms: New Organizational Form or Variations on a Theme? Industrial and Corporate Change, 15 (1), 77-99.

Williams, T., Freeman J., Shoesmith, E., Anderson, D., \& Sweeney, D. (2017). Statistics for Business and Economics. Cengage Learning EMEA. 